\title{
Změny aktuálních psychických stavů způsobené cvičením aqua aerobiku a jejich vliv na subjektivní pohodu u vysokoškolských studentek s disabilitou
}

\section{Change of current mental conditions caused by aqua aerobic exercise and their impact on subjective well-being among university students with disability}

\author{
Hana Janošková ${ }^{1}$, Marie Blahutková ${ }^{2}$ \\ ${ }^{1}$ Pedagogická fakulta, Masarykova univerzita, Brno, Česká republika \\ ${ }^{2}$ Fakulta sportovních studií, Masarykova univerzita, Brno, \\ Česká republika
}

Abstrakt:

V našem výzkumném šetření jsme se zaměřili na problematiku zjištováni aktuálních psychických stavi̊, zejména subjektivni spokojenosti u studentek MZLU s disabilitou, které navštěvovaly pravidelnou výuku tělesné výchovy ve formě aqua aerobiku. Při pohybu ve vodě je jedinec vystaven působení řady vlivů. Př́jemný pocit člověka při pobytu ve vodě záleži na tom, jak se jeho organizmus vyrovná s působením teploty vody a s hydrostatickým tlakem. Výzkum byl prováděn po dobu jednoho semestru ve formě dotaznikového šetření, rozhorů a pozorování. Zjistili jsme, že studentky s disability (zraková a sluchová) vykazují vyšší skóre kladných odpovédí v pozitivním pưsobení vody na jejich subjektivní pohodu, cití se zdravěji a při pohybu ve vodě se cítí svobodnější. Po ukončení výuky posuzovaly kladně vliv vody a pravidelného cvičení na úzkostné stavy a na vyšši kvalitu života. Otázkou může být, do jaké míry 
jsou tyto stavy způsobeny pouze cvičením. Mohou je ovlivňovat i jiné faktory, nap̌r. prostředi, ve kterém lekce probihaly, osobnost cvičitele, ale i dobrá spolupráce ve skupiné.

\section{Abstract:}

In our research we focused on the issues of detecting actual mental states, especially the subjective satisfaction of the Mendel University students with disability who attended regular classes of physical education in the form of aqua aerobics. While moving in water the individual is exposed to a number of factors. Pleasant feeling when a person stays in the water depends on how his body copes with the effects of water temperature and hydrostatic pressure. The research was carried out over a period of one semester in the form of a questionnaire surveys, interviews and observations. We found out that students with a disability (visual and auditory) show higher scores of positive responses in the positive effect of water on their subjective well-being, feel healthier and moving in the water feels freer. After completing the course positively evaluated the influence of water and regular exercise on anxiety and higher quality of life. The question may be to what extent these states are only caused by exercise. The states may be influenced by other factors such as the environment in which lessons were held, celebrity trainer, but also a good cooperation in the group.

Klíčová slova: zdraví, aqua aerobik, studentky VŠs disabilitou, subjektivní pohoda.

Key words: Health, Aqua aerobic, University Students with disabilities, Subjective Well-Being.

\section{PROBLÉM PRÁCE}

Možnosti využívat tělesnou výchovu jako volitelný předmět při studiu na vysoké škole nenabízí v dnešním vysokoškolském prostředí běž- 
ně každá vysoká škola. Na mnoha typech vysokých škol povinná tělesná výchova zcela chybí nebo je nabízena formou placené služby (napřr. VUT), na některých se objevuje jako povinný předmět v 1. nebo 2. ročníku studia (např. na MU). Na Mendelově zemědělské a lesnické univerzitě (MZLU) v Brně mají studenti možnost volit si z řady nabízených sportovně pohybových aktivit, přitom většina $\mathrm{z}$ nich je hrazena vnitřními prostředky školy. Pouze nabízené sporty, které jsou finančně náročnější, si musí studenti doplácet.

Při výzkumném šetření pro výzkumný úkol jsme se zaměřili na změny aktuálních psychických stavů u vysokoškolských studentů a studentek, které mohou být způsobeny vlivem pravidelného cvičení. Pro výzkum jsme zvolili aktuální a velmi navštěvovaný aqua aerobik. Zjistili jsme, že o tuto aktivitu mají zájem také studentky s disabilitou. Protože jich však nebylo dostatek, abychom mohli vytvořit samostatnou skupinu, byli integrováni podle možností do jednotlivých výukových skupin.

Pohyb je základním výrazovým prostředkem člověka, jazykem jeho pocitů a nálad, je prvotní formou prastaré lidské komunikace (Mužík \& Krejčí, 1997). Pravidelnou pohybovou aktivitou přispíváme k naplňování duševní rovnováhy a ke kvalitě života člověka. Pojem kvalita života je pojem multidimenzionální, dlouhodobě a složitě se vytvářející, značně relativistický, idealizovaný a nedosažitelný. Vždy souvisí s řadou okolností a v průběhu lidského života se náhled na něj mění. Mladá generace v posledních dvaceti letech, zejména však na počátku nového tisíciletí, klade důraz zejména na ekologické souvislosti kvality života a sociálně nebo globálně kritické momenty pojmu (Blahutková, Řehulka \& Dvořáková, 2005). Tento pojem je v současnosti podrobován řadě výzkumů a analýz a do souvislosti se dávají jednotlivé komponenty, které mohou kvalitu života ovlivňovat. Otázkami kvality života se zabývají odborníci na celém světě. Uvnitř vědy i uvnitř jednotlivých kultur je na pojem kvalita života nahlíženo zcela odlišně. Lze jen stěží hledat diskrepance mezi pochopením tohoto pojmu i uvnitř jednotlivých vědeckých disciplín v důsledku vědeckého konstruování i v důsledku vlastních procesů (filozofie, medicína, sociální vědy apod.). Giddens (1999) u tohoto pro- 
blému předpokládá dvojitou hermeneutiku, tedy průnik dvou významových rámců, který je nezbytnou součástí sociální vědy. Do politiky se pojem kvalita života dostal v 60. letech minulého století, jeho autory jsou američtí prezidenti Kennedy a Johnson (Kř́žzová, in Payne et al. 2005, s. 218). Často bývá tento pojem slučován s materiálními hodnotami (růstem ekonomického potenciálu jednotlivce i skupiny). Z hlediska pojetí duchovního a sociálního je tento pojem vztahován více k postmateriálním hodnotám a tím je chápán zejména přechod k postmoderně. Objevují se alternativní životní způsoby ve smyslu vědomého zřeknutí se zbytečného a samoúčelného konzumu (tzv. programový simple life) a současně je pozorován sklon $\mathrm{k}$ hédonistickému požitkářství, snaze usnadnit si plnění všedních potřeb a žít ještě plnohodnotněji. Pokud možno při zkrácení vzdálenosti mezi touhou a požitkem (Baumann, 1995). Podle některých autorů je kvalita života především záležitostí hodnot. Ty sice částečně závisejí na osobní volbě, ale to, co je posuzováno jako dobré nebo špatné, je ve značné míře bezprostředně diktováno kulturou a společností (Hofstede, 1984). Ze sociologického pohledu je typické přesvědčení, že pojem je výrazně sociokulturně determinován. $Z$ těchto úvah vyplývá, že lidé v různých zemích mají na pojem kvalita života zcela odlišný názor. $\mathrm{V}$ rámci globalizace je možné předpokládat, že se budou objevovat nesčetné konvergence různých prvků, a především se objeví rozpad jednotné představy o kvalitním životě. Vše je dáno multikulturalitou a transkulturou, které ukazují v posledním desetiletí na rozpad hranic národních kultur a jejich geografickou návaznost. Kvalitu života můžeme změřit pomocí kvalitativních výzkumů, různých dotazníkových a anketních šetření, pozorování, rozhovorů a subjektivního hodnocení. První pokusy měření kvality života se objevily ve zdravotnictví, v souvislosti s onemocněním onkologických pacientů a seniorů. Předchůdcem měření kvality života bylo tzv. health state (HS) - rejstř́ky zdravotního stavu konkrétního pacienta, př́padně souboru jeho zdravotních problémů. Snahou bylo nastínit zdravotní stav z lékařského pohledu (fyziologické hledisko).

V souvislosti s kvalitou života se neustále více odborníci zabývají možnostmi využívání pohybových aktivit zejména pro zdraví, nejed- 
ná se tedy ani o vrcholový nebo výkonnostní sport, ale pouze o pohyb ve smyslu rekreačním a ve smyslu zdravotně orientovaném. V této rovině by měla pohybová aktivita směřovat ke zlepšení nálady, ke vnímání souvislostí pohybu a tělesnosti a ke zlepšování psychické pohody každého zúčastněného. Při podrobnějším zkoumání kognitivních kompetencí u jednotlivců můžeme hovořit o tom, že chování osobnosti v procesu pohybových aktivit a jeho znaky variují s ohledem na rozsah situací, ve kterých jsou projevy pohybu přiměřené (Dlouhá \& Dlouhý, 2012). Pohyb tedy př́mo působí na psychickou složku člověka, zejména na jeho vyrovnanost a schopnost lépe vnímat naše aktuální psychické stavy. Tyto mohou ovlivňovat nejen naše postoje a naši komunikaci, nýbrž i náš životní postoj a později celý životní styl.

Aqua aerobik je forma kondičního cvičení při hudbě ve vodě, zatěžující jak srdeční a dýchací soustavu, tak i pohybové ústrojí pobytem a lokomocí ve vodě. Zahrnuje cvičení v různé hloubce vody s motivačním využitím hudby. Aqua aerobik má řadu pozitivních vlivů, nap̌r. výjimečné vlastnosti vody způsobují, že cvičení se stává bezpečným, efektivním a dostupným všem, aerobik ve vodě je skvělou zábavou, kromě ponoření nám dává pocit soukromí a zároveň se můžeme začlenit do kolektivu cvičenců, vztlak vody má vliv na odlehčení kloubů a páteře, odpor vody umožňuje rozvoj svalové síly, vytrvalosti a flexibility. Aqua aerobik je ideálním cvičením pro posttraumatické stavy, je vhodný i pro nesportovce a starší osoby, cvičení se mohou účastnit i osoby se silnou nadváhou, má pro ně velmi pozitivní vliv, riziko poranění je nízké, vztlakovou silou vody se mnohonásobně redukuje tělesná hmotnost (Janošková \& Muchová, 2002).

Ve vodě je větší riziko nesprávného provedení pohybu než na suchu. Způsobuje to nestabilita postoje, polohy. Ve vodě je dosažení rovnováhy obtížnější. Nároky na rovnováhu, na balanční dovednosti jsou vysoké, musí vést $\mathrm{i} k$ nácviku vyrovnávacích pohybů při větších pohybech těžiště. Aqua gymnastika a aqua aerobik mají vlivem vlastností vodního prostředí omezenější pohybový repertoár činností, ale naopak jsou cvičení, která lze zase provádět výlučně ve vodním prostředí. Hloubka vody by 
při cvičení neměla přesahovat po prsa, aby byl vždy zajištěn pevný postoj cvičenců (Muchová \& Janošková, 2004). V hlubší vodě, kde je tendence stát na špičkách, často dochází k přetěžování hýžd'ového a lýtkového svalstva cvičením ve výponu. Jde o nevhodnou kompenzaci vlivu vztlaku. Udržet se na cvičebním místě v závislosti na hloubce vyžaduje různé úsilí, a tím je určena i různá intenzita pohybů udržujících rovnováhu (Rodriguezová-Adamiová, 2005). Bylo prokázáno, že vlivem aerobních aktivit prováděných ve vodním prostředí dochází také $\mathrm{k}$ redukci stresu a úzkostných stavů (Krejčí \& Man, 1990). Aqua aerobik je vhodným aerobním cvičením pro všechny, kteří jsou schopni aerobní činnosti provozovat, včetně různých disabilit. Studentky s disabilitou, které se výuky zúčastnily, měly všechny předpoklady k tomu, aby výuku mohly absolvovat.

Období vysokoškolského studia je pro mladé lidi období rozvoje duševního vnímání a rozumového chápání. Přri zkoumání osobnosti vždy musíme respektovat všechny zákonitosti, které výzkum osobnosti provázejí, a důležité je respektovat osobnost jako celek s určitým zaměřením a charakteristikami, které jsou jedinečné. Vždy musíme vycházet z rámcového předpokladu, že osobnostní příčinou chování nebo prožívání málokdy bývá mechanicky působící jednotka osobnosti (k výjimkám patří pohybový neklid). Př́ičina prožívání nebo chování většinou tkví v realizaci určitého plánu, úmyslu, cíle, který si osobnost ani nemusí plně uvědomovat (Smékal, 2002). Osobnost studentů vysoké školy je dána řadou specifických charakteristik, u kterých bychom našli řadu shodných faktorů, ženy se odlišují v mnoha znacích od mužů, přičemž jejich společným cílem je dostudovat a získat potřebná uznání.

Osobnost je výsledkem mnoha faktorů, mezi kterými dominují genetické předpoklady a historicky společenské prostředí. Osobnost je neopakovatelná ve své individuálnosti, v jednotě svých zkušeností, kladů a záporů, zděděných a získaných vlastností (Rozenthal, 1966). Má řadu specifických vlastností, které můžeme rozdělit na vlastnosti primární a sekundární. Primární vlastnosti jsou představovány vrozenými dispozicemi osobnosti vykonávat nějakou činnost a projevují se v nich rodo- 
vá specifika. Patří k nim například organické potřeby nebo temperament. Sekundární vlastnosti jsou ty, které člověk získal v průběhu vlastní ontogeneze, jsou však závislé na vlastnostech primárních.

\section{CÍLE, VÝZKUMNÉ OTÁZKY A ÚKOLY VÝZKUMU}

Hlavním cílem naší práce bylo zjistit podíl pohybových aktivit s náplní aqua aerobiku na aktuální životní spokojenost u handicapovaných studentek vysokých škol. Dílčím cílem je vymezení podílu této činnosti na prožitkové sféře osobnosti, včetně zdravotních aspektů. Při stanovení cílů práce jsme vycházeli z poznatků moderní psychologie a kinantropologie a současně jsme navázali na plány MŠMT v oblasti vytváření podmínek pro vysokoškolské studenty, které přispívají k růstu harmonicky rozvinuté osobnosti vysokoškolského studenta ve všech oblastech, tedy i z hlediska pohybové výchovy a tělesné aktivity.

Současné vedení MZLU v Brně podporuje Ústav tělesné výchovy a jeho aktivity v rámci nepovinné tělesné výchovy, chtěli jsme naší prací přispět k podpoře sportovně pohybových aktivit a současně poukázat na význam pohybu pro každého vysokoškolského studenta. Součástí našeho cíle práce bylo vymezení rozdílů mezi prožíváním u studentek s disabilitou a u studentek bez tělesného omezení.

Stanovili jsme si dvě výzkumné otázky:

1. Jak ovlivní pohybové aktivity s náplní aqua aerobiku snížení pocitu únavy a vyčerpanosti u studentek vysokých škol a existují rozdíly mezi studentkami disabilitou a studentkami bez tělesného omezen?

2. Jaký vliv mají pohybové aktivity s náplní aqua aerobiku na životní spokojenost studentek vysokých škol?

K tomu, abychom mohli tyto výzkumné otázky ověrit, jsme stanovili úkoly práce, které se týkaly zejména:

- prostřednictvím dotazníkového šetření zjistit podíl aqua aerobiku na odbourávání únavy u vybraného souboru studentek vysoké školy (8SQ);

- zjistit vliv aqua aerobiku na aktuální životní spokojenost pomocí dotazníkového šetření. 


\section{METODIKA}

$\mathrm{K}$ tomu, aby studentky s disability mohly být zařazeny do výukových skupin, jsme využili možnost rožrazení podle výukového programu a současně jsme požádali zájemce o spolupráci a o souhlas se zařazením do výzkumného souboru. Všechny předložily souhlas lékaře s pravidelnou tělesnou výchovou.

Lekce aqua aerobiku v roce, kdy jsme prováděli výzkumné šetření a intervenční program, navštěvovalo celkem 70 studentek ve věku 18-26 let, věkový průměr byl 22,4 let. $\mathrm{S}$ výzkumným šetřením souhlasilo 60 studentek, z toho $7 \mathrm{z}$ nich vykazovalo známky disability, 2 byly zrakově oslabené ( $1 \times$ slabozrakost, $1 \times$ strabismus) a 2 byly sluchově oslabené a 2 s lehkou formou DMO.

Studentky si tělesnou výchovu vybraly dobrovolně a z 15 nabízených pohybových aktivit si zvolily právě lekce aqua aerobiku. I přesto, že účast na hodinách tělesné výchovy je dobrovolná, lze konstatovat, že účast na výuce aqua aerobiku byla téměř stoprocentní. Výuka probíhala v pondělí 11-12 hod. a ve čtvrtek 14-15 hodin v jarním semestru školního roku 2009/2010.

Lekce aqua aerobiku probíhaly $1 \times$ týdně. Délka lekce se pohybuje od 40 do 45 minut. Cvičení bylo vždy doprovázeno hudebním doprovodem. Lekce aqua aerobiku probíhaly v přechodné vodě.

\section{Použité metody:}

\section{Lekce aqua aerobiku:}

Skladba cvičební lekce:

1. Warm up I. - zahřátí (př́íprava organizmu na zátěž).

Doba trvání: 5 minut.

2. Warm up II. - zvyšování intenzity prodlužováním páky, pohybem z místa (pro dosažená aerobního pásma.

Doba trvání: 5 minut

3. Hlavní část - zatížení organizmu, intenzita cvičení dosahuje svého maxima. 
Doba trvání: 25 minut.

4. Cool down - pozvolné snižování intenzity cvičení.

Doba trvání: 5 minut.

5. Warm down - znovu rozehřátí organizmu, cvičící mají pocit tepla (např. walking).

Doba trvání: 5 minut.

Cvičící mohou opouštět bazén po ukončení cvičení (v našem př́ípadě byla délka lekce aqua aerobiku $45 \mathrm{~min}$ ), zájemci pokračovali ještě 10 min. vyplaváním (Janošková \& Muchová, 2002).

\section{Dotazník osmi stavů (8 SQ):}

Pro výzkum jsme zvolili Dotazník osmi stavů (8 SQ), který byl záměrně sestaven pro diagnostiku osmi základních emočních stavů a nálad (Cattell \& Curran, 1986). Teoretický význam diagnostiky emočních stavů je založen na skutečnosti, že každá predikce lidského chování a jednání je závislá stejně na jeho momentálním stavu jako na jeho trvalejších rysech.

Cílem 8SQ je prezentovat mnohostavovou baterii nejširšího spektra podle současného stavu vědeckého bádání. V mnoha typech situací je žádoucí nejprve prozkoumat reakce podle jejich závislosti na strukturách různých druhů emočních stavů. Dotazník lze používat v různém prostředí i v různých podmínkách (napřs. před zátěží, po zátěži) u jednotlivců i u skupin. V dalším šetření jsme se zaměřili na subjektivní pohodu u studentů, která může velmi pozitivně ovlivnit jejich studijní výsledky, ale i jejich kvalitu života.

Výzkum jsme realizovali prostřednictvím intervenční proměnné, kterou byla pravidelná pohybová aktivita ve formě aqua aerobiku.

Jedná se o standardizovaný dotazník, který se využívá ke zjišt'ování emočních stavů. Dotazník využívá mnohastavovou baterii, která poskytuje uživatelům charakteristiky celé pestrosti emočních reakcí, jež jsou vyvolávány různými situacemi nebo jejich změnami. Pro některé př́ipady může být důkladné poznání komplexnosti emočních reakcí jedince na situaci klíčovým zjištěním. Například nová metoda se může osvědčit při 
snižování anxiety, může však mít nechtěné vedlejší účinky na její úroveň. Kdyby tedy byl zjišt'ován pouze faktor anxiety, relevantní informace by se mohla ztratit.

Dotazník zkoumá celkem osm stavů na škálách: Anxieta, Stres, Deprese, Regrese, Únava, Pocit viny, Extravertnost, Vysoká aktivace (arousal).

Test je složen z osmi škál a jsou vypočítány skóry na dvanácti položkách v každé formě. Dotazník je standardizovaný. Každá otázka má čtyři varianty odpovědí. Skór každé položky se vztahuje vždy pouze na jeden faktor. Test lze provádět individuálně i skupinově. V našem výzkumu jsme používali skupinovou formu (vždy v jedné lekci celá skupina, která souhlasila s výzkumným šetřením, ostatní plavali).

\section{Osobní anketa}

Abychom mohli lépe popsat jednotlivce i skupinu oslovených studentek, sestavili jsme osobnostní anketu pro studentky a v ní jsme zjištovali zájem studentek o lekce aqua aerobiku, o cvičení, jejich názory na nabízené formy tělesné výchovy a každá z oslovených studentek se mohla libovolně vyjádřit $\mathrm{k}$ problematice nepovinné tělesné výchovy i k osobnosti cvičitelů jednotlivých forem nabízené tělesné výchovy.

\section{VÝSLEDKY A DISKUZE}

Pro odpověd' na výzkumnou otázku 1 jsme použili vyhodnocení získaných výsledků z Dotazníku subjektivní pohody mládeže. Celkově vyšší spokojenost se objevovala u studentek po ukončení lekcí. Vstupní hodnoty sebehodnocení byly aktuálně u psychických problémů vyšší než u ostatních komponent. U této oblasti byla nalezena také statistická významnost s položkou subjektivní spokojenost. Ke změně došlo u aktuálně psychických problémů v pozitivním smyslu, na konci výzkumu označily tuto položku oslovené studentky jako nižší než v úvodním testování. Tato komponenta reprezentuje aktuální aspekt subjektivní pohody, tedy pohodu v konkrétním časovém údaji. Může se měnit pod vlivem řady proměnných, které v průběhu výuky mohou studentky ovlivnit. 
Základní informace pro vstupní šetření jsme získali u souboru oslovených studentů z osobní ankety (celkem 350 odpovědníků). Protože únava a vyčerpanost souvisí se zdravím, první otázkou byl subjektivní pocit zdraví. Proto jsme se ptali na zdravotní problémy v osobní anketě. Většina studentů označila svoje zdraví za dobré, zdravotní potíže se objevily u 15 studentů (obr. 1).

Při následných rozhovorech jsme zjistili, že pouze některé studentky trpí vážnějším onemocněním, kladná odpověd’ znamenala v šesti případech akutní infekční onemocnění. Pět studentek trpělo závažnými zdravotními obtížemi.

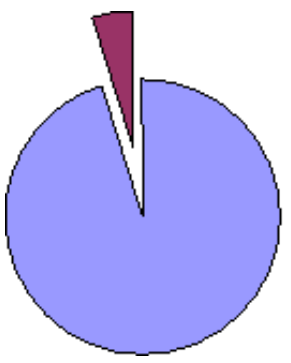

Obr. 1: Počet studentek, které se necití zdravé ve zkoumaném souboru $(N=60)$

Dotazovali jsme se, zdali studentky, které se zúčastnili nepovinné tělesné výchovy, při cvičení aqua aerobiku pocitovaly při cvičení pozitivní pocity. Na tuto otázku neodpovědělo celkem 177 studentek (zřejmě se cvičení aqua aerobiku nezúčastnily). Celkem 145 oslovených odpovědělo kladně, pouze 4 měli pocit, že cvičení aqua aerobiku př́ijemné pocity nevyvolává (obr. 2). Z praxe víme, že cvičení přináší všem zúčastněným kromě zdravotních benefitů právě př́jemné pocity. U těchto pocitů se objevuje také fyziologická reakce organismu, protože tělo vyplavuje již během cvičení endorfiny a proto jsou většinou po fyzickém zatížení 
lidé velmi spokojeni. Cvičení samozřejmě přináší i další pozitivní účinky na zdraví (svalový aparát, dýchací systém apod.), je tedy nezbytnou součástí našeho života. V rámci harmonického rozvoje osobnosti je nutné pravidelně cvičit, protože studentky většinu studia sedí v posluchárnách nebo v učebnách.

Totéž jsme zjišt'ovali po ukončení cvičební lekce, tedy zdali cvičení vyvolává po ukončení pozitivní pocity. Přestože odpověděl stejný počet studentek, odpovědi se od předchozí otázky lišily. Tentokrát neodpovědělo 180 studentek. 142 studentek má pocit, že po cvičební lekci mají pozitivní pocity. U čtyř studentek se opět objevila odpověd' ne (tab. 1).

Při podrobné analýze odpovědí studentek disability jsme zjistili, že jejich odpovědi se nijak nelišily od odpovědí ostatních studentek, ani v jednom případě se v odpovědích neobjevily negativní pocity, vyšší anxieta nebo jiné potíže. Studentky s oslabením zrakovým naopak uváděly, že se u nich zlepšily pocity vnímání vody a na cvičení se těšily, protože u nich docházelo k velkému propojení vnímání pocitů vody s radostným pohybem a současně s hudebním doprovodem.

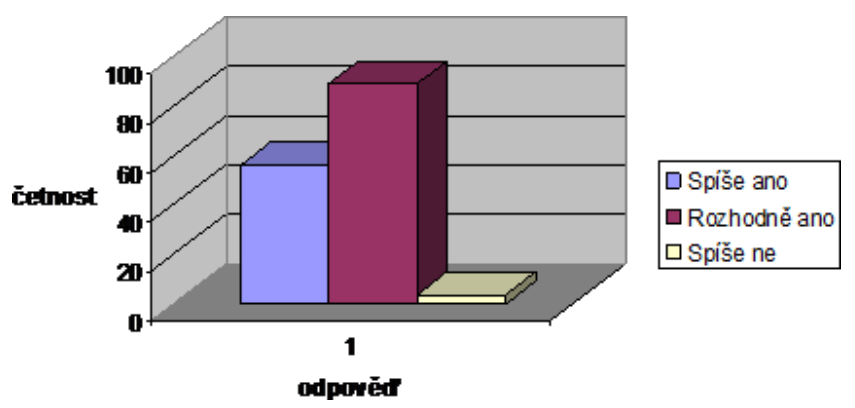

Obr. 2: Odpověd' na otázku zda vyvolává cvičení aqua aerobiku pozitivní pocity 
Change of current mental conditions caused by aqua aerobic exercise and their impact on subjective well-being... Změny aktuálních psychických stavů způsobené cvičením aqua aerobiku a jejich vliv na subjektivní pohodu...

Tab. 1: Odpovědistudenteknaotázku,jakse citípocvičebnílekci $(N=326)$

\begin{tabular}{|l|l|l|l|l|}
\hline \multirow{3}{*}{ Kategorie } & \multicolumn{4}{|l|}{$\begin{array}{l}\text { Tabulka četností: Cvičení aqua aerobiku u Vás } \\
\text { po ukončení hodiny vyvolává pozitivní pocity } \\
\text { (upravena data) }\end{array}$} \\
\cline { 2 - 5 } & Četnost & Kumulativní & Rel. četnost & Kumulativní \\
\hline spíše ano & 50 & 50 & 15,33742 & 15,3374 \\
\hline- & 180 & 230 & 55,21472 & 70,5521 \\
\hline rozhodně ano & 92 & 322 & 28,22086 & 98,7730 \\
\hline spíše ne & 4 & 326 & 1,22699 & 100,0000 \\
\hline ChD & 0 & 326 & 0,00000 & 100,0000 \\
\hline
\end{tabular}

V Dotazníku osmi stavů se objevuje pocit únavy v několika složkách. V depresi, ve stresu, částečně v anxietě a hlavně v únavě (tab. 2). Tyto položky spolu úzce souvisejí a jejich úroveň ukazuje na skutečné vyčerpání člověka v průběhu každodenní činnosti. U vybraného souboru jsme sledovali všechny složky a vyhodnotili je se vztahem k pocitům zdraví a subjektivním pocitům pohody. Mnohé se podivily nad získanými výsledky, protože subjektivně žádné potíže nepocitovaly, přitom hodnoty byly ověřeny několika způsoby (test stresu, Dotazník osmi stavů, Test subjektivní pohody mládeže).

V Dotazníku osmi stavů se projevily závislosti, které jsme statisticky vyhodnotili pomocí korelace a výsledky párového t-testu (tab. 3). Vybrali jsme studentky, které označily v odpovědi kladně pocity, které byly zahrnuty do složek únavy a vyčerpanosti.

Na počátku výuky se studentky při výuce pohybovaly v oblasti únavy v pásmu $5 \mathrm{~s}$ hrubým skórem 9-14 bodů, na konci výuky se posunuly do pásma $4 \mathrm{~s}$ hrubým skórem 7-8 bodů. Při srovnání s běžnou populací je to mírně pod průměrem (populace má stenový skór 13,96 se směrodatnou odchylkou 7,43), zkoumaný soubor byl tedy ve výši únavy na počátku realizace lekcí aqua aerobiku 0,5 sigmy pod průměrem populace, po ukončení výuky 0,5 sigmy nad průměrem populace. 
U studentek s disabilitou jsme zaznamenali již na počátku cvičení mírně zvýšený stenový skór oproti ostatním studentkám, vzhledem k malému počtu zapojených studentek však nebylo možné získané výsledky statisticky vyhodnotit.

$\mathrm{Z}$ uvedeného lze konstatovat, že skutečně lekce $\mathrm{s}$ náplní aqua aerobiku ovlivňuje pozitivně snižování pocitu únavy a subjektivní pocity stresu nebo negativních nálad. Studentky se po ukončení cvičení vždy usmívaly a byly plné optimizmu a elánu do další práce.

Naopak v úvodní anketě některé studentky ihned označily nezájem o nabízenou nepovinnou tělesnou výchovu ve formě aqua aerobiku. Jako důvod nezájmu o tuto pohybovou aktivitu uváděly zejména neznalost kolektivu cvičících a strach $\mathrm{z}$ neznámého prostředí. V některých odpovědích se objevovala obava ze špatného prostředí anebo z nízké teploty vody. K této problematice se vyjádřilo celkem 326 studentek. V testech subjektivní spokojenosti jsme zjistili, že skupina studentek vykazovala po ukončení cvičení aqua aerobiku odlišné hodnoty, než na počátku cvičení. $\mathrm{U}$ jednotlivých komponent se nejvíce projevily rozdíly $\mathrm{v}$ komponentě pozitivní postoj k životu a depresivní nálada. U vybraných komponent jsme se zabývali změnami, které se projevily po ukončení cvičebních lekcí, zaznamenali jsme nejnižšś a nejvyšší skóre, které jednotlivci i skupiny dosáhli. Lze říci, že výsledky nebyly statisticky významné, prokázala se pouze věcná významnost (obr. 3).

Tab. 2: Statistické hodnoty u vybraných položek Testu 8 SQ u jednotlivých měrení

\begin{tabular}{|l|l|l|l|l|}
\hline Složka & 1. měření & $\begin{array}{l}\text { Směrodatná } \\
\text { odchylka }\end{array}$ & 2. měření & $\begin{array}{l}\text { Směrodatná } \\
\text { odchylka }\end{array}$ \\
\hline Depresivita & 4,50 & 2,19 & 3,88 & 1,59 \\
\hline Stres & 8,33 & 4,39 & 10,53 & 3,72 \\
\hline Anxieta & 4,81 & 2,17 & 3,88 & 1,45 \\
\hline Únava & 2,13 & 1,06 & 3,67 & 1,84 \\
\hline
\end{tabular}


Tab. 3: Statistické vyhodnocení vybraných položek Testu 8 SQ

\begin{tabular}{|l|l|l|l|l|}
\hline Složka & Korelace & $\mathrm{P}$ (korelace) & $\mathrm{P}(\mathrm{t}$-test) & $\mathrm{N}$ \\
\hline Depresivita & 0,225 & 0,314 & 0,664 & 22 \\
\hline Stres & 0,354 & 0,106 & 0,968 & 22 \\
\hline Anxieta & 0,206 & 0,358 & 0,033 & 18 \\
\hline Únava & 0,289 & 0,244 & 0,042 & 22 \\
\hline
\end{tabular}

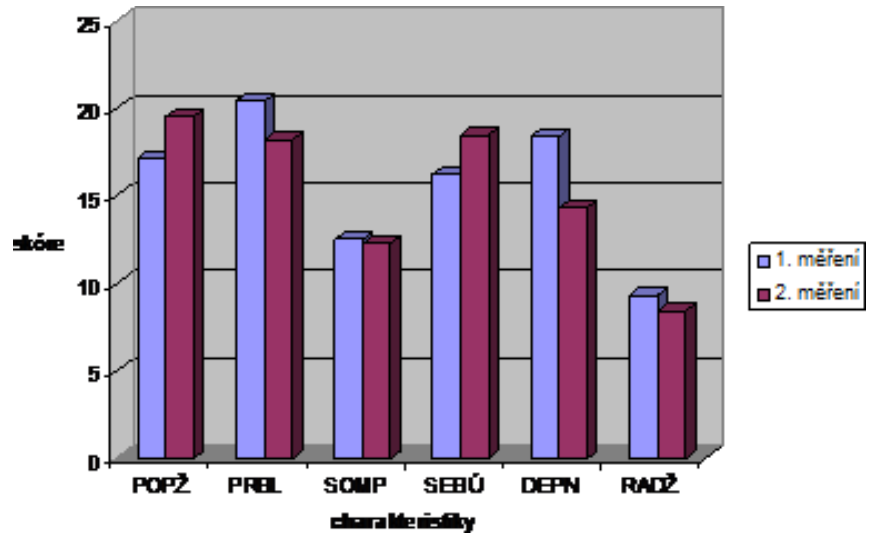

Obr. 3: Posun skóre u jednotlivých položek u Dotazníku subjektivní pohody

Legenda: POPŽ Pozitivní postoj k životu, PRBL Proživané problémy, SOMP Somatické potiže, SEBÚ Sebeúcta, DEPN Depresivní nálady, RADŽ Radost v životě

\section{ZÁVĚR}

Naše práce přinesla řadu poznatků, které mohou obohatit práci učitelů na MZLU a které poukazují na velký význam sportu a sportovně pohybových aktivit pro studenty vysokých škol. Výsledky práce jsme podrobili statistické analýze dat, a proto můžeme odpovědět na stanovenou vědeckou otázku práce následovně: 
Závislost mezi pravidelným prováděním aqua aerobiku a životní spokojeností (včetně aktuální životní spokojenosti) u studentek vysokých škol existuje. Je velmi významná.

K odpovědím na výzkumné otázky se nám podařilo zajistit dostatek výsledků, lze tedy konstatovat, že pravidelné pohybové aktivity pozitivně ovlivňují snižování pocitů únavy a současně pozitivně působí na snížení pocitů vyčerpanosti. Studentky se cítily uvolněné, nabité energií a měly chut' do další práce. Mezi studentkami s disability a studentkami bez potíži jsme nenalezli žádné statisticky vyznané rozdíly. Protože bylo studentkám umožněno začlenění do nabízených cvičebních lekcí, domníváme se, že nepocitovaly v rámci svého oslabení znevýhodnění. Veškeré nabízené aktivity prováděly s plným nasazením a stejně jako ostatní studentky. V rozhovorech po ukončení výzkumu se vyslovily pro další spolupráci.

Pohybové aktivity s náplní aqua aerobiku působí na snižování subjektivních pocitů únavy a také na celkovou životní spokojenost studentek MZLU. Vliv je tedy pozitivní.

\section{LITERATURA}

Baumann, Z. (1995). Úvahy o postmoderní době. Praha: Sklon.

Blahutková, M., Řehulka, E. \& Dvořáková, Š. (2005). Pohyb a duševní zdraví. Brno: Paido.

Cattel, R. B., Curran, J. P. (1973). Personality and mood by questionnaire. San Francisco: Jossey-Bass.

Dlouhá, J. \& Dlouhý, M. (2012). Sociálni opora hospitalizovaného ditěte. Praha: Pf UK.

Giddens, A. (1999). Sociologie. Praha: Argo.

Hofstede, G. (1984). The Cultural Relativity of the Quality of Life Concept. Academy of Management Review. vol. 9. p. 389-398.

Janošková, H. \& Muchová, M. (2002). Aqua aerobik. Brno: Paido. 2002. ISBN 80-7315-030-1.

Krejčí, M. \& Man, F. (1990). Využití tělesných cvičení ke snižování stresu, úzkosti a depresívních stavů. In: Teorie a Praxe Těl. Vých. 38, 1990/1. s. 53-60. ISSN 0040-358X. 
Křŕžová, E. (2005). Sociologické podmínky kvality života. In J. Payne et al. Kvalita života a zdraví (pp. 351-364). Praha: Triton.

Muchová, M. \& Janošková, H. (2004). Aqua fitness. Brno: Paido. ISBN 80-7315-076-X.

Mužík, V. \& Krejčí, M. (1997). Tělesná výchova a zdraví. Olomouc: Hanex.

Rodriquezová-Adamiová, M. (2002). Akvafitness. Praha: Euromedia Group.

Rozenthal, R., J. (1966). Trachet expectancies. Determinant of pupils IQ gains. In: Psychological Reports. No. 19. p. 34-46.

Smékal, V. (2002). Pozvání do psychologie osobnosti. Brno: Barrister \& Principal.

\section{KONTAKT:}

PaedDr. Hana Janošková, Ph.D., janoskova@ped.muni.cz 